\begin{tabular}{lcr} 
FOLIA & ENTOMOLOGICA & HUNGARICA \\
& ROVARTANI KÖZLEMÉNYEK & \\
Volume 81 & 2020 & pp. $73-79$ \\
\hline
\end{tabular}

\title{
First record of Ophraella communa in Hungary (Coleoptera: Chrysomelidae)
}

\author{
Dávid HoRvÁTH ${ }^{1 *} \&$ Márk LuKÁTSI ${ }^{2}$ \\ ${ }^{1}$ Department of Entomology, Faculty of Horticultural Science, Szent István University, H-1118 \\ Budapest, Villányi út 29-43, Hungary.E-mail: horvathdow@gmail.com \\ ${ }^{2}$ H-1223 Budapest, Kamaraerdei út 8, Hungary.E-mail:lukatsi88@gmail.com
}

\begin{abstract}
Ophraella communa LeSage, 1986, a leaf beetle native to North America, is recorded for the first time from Hungary. Several specimens were found on a degraded meadow in the outskirts of Budapest. Its importance in suppressing its main host plant, common ragweed (Ambrosia artemisiifolia L.), is shortly discussed, as well as the potential problems it can cause in plant protection. With 5 figures.
\end{abstract}

Key words - natural enemy, biological control, leaf beetle, ragweed

\section{INTRODUCTION}

The genus Ophraella Wilcox, 1965 contains 14 species, which are distributed in North-America (LESAGE 1986). All species are specialised to feed on Asteraceae plants. Some of them are monophagous on certain species that makes them an appropriate choice for biological control of some weeds worldwide (GOEDEN \& RICKER 1985, GERBER et al. 2011).

The most significant of these species is Ophraella communa LeSage, 1986 which is widespread in its original area from Mexico to Canada. Out of its original distribution, stable populations thrive in south-eastern Asia and Europe. Since its first occurrence in Europe in 2013, O. communa is reported from several European countries such as Italy, Switzerland, Slovenia and Croatia (MÜLLER-SCH ÄRER et al. 2014, ZADRAVEC et al. 2019, ZANDIGIACOMO et al. 2020). Its main host plant is the common ragweed (Ambrosia artemisiifolia L.) that causes serious agricultural and human health problems worldwide as it produces highly allergic pollen (KAZINCZI et al. 2008). Due to the weed's high importance, the occurrence of $O$. communa in Europe has drawn much attention. Despite that the distribution models dealing with the species show that the climatic conditions in most of

* Corresponding author. 
Hungary do not meet the requirements of O. communa (AUgustinus et al. 2019), the authors have found a population in Budapest, Hungary.

Abbreviations - $\mathrm{CDH}=$ private collection of Dávid Horváth (Szekszárd, Hungary); CLM = private collection of Márk Lukátsi (Budapest, Hungary); HNHM = Hungarian Natural History Museum (Budapest, Hungary).

\section{MATERIALS AND METHODS}

On 3 September 2020 on a Hungarian citizen science webpage (https://www.izeltlabuak.hu) a picture of a beetle was uploaded that seemed to be similar to O. communa. The uploader attached the exact date and location of the finding (https://www.izeltlabuak.hu/talalat/147178). On 6 September 2020 , we visited the place given by the coordinates. It was a degraded, disturbed weedy meadow with lot of ragweed (Fig. 1). After a short search we found the first beetle sitting on its host plant (Fig. 2). With sweep-netting and visual inspection of the plants we collected, and photo documented 10 further adults, several egg batches (Fig. 3), one larva (Fig. 4) and one pupa (Fig. 5). After the first location, we visited a nearby meadow and a weedy canal side, $2 \mathrm{~km}$ to the north. The result of collecting in all three locations was the above-mentioned 11 specimens (see Material examined for details). Specimens have been deposited in the private collection of the authors and the Coleoptera Collection of HNHM.

Ophraella can be differentiated from other European galerucine genera by its longer pubescence that contains more or less erect setae. In addition, its elytral pattern is unlike any native Hungarian species. Thus the identification of the specimens was based on the external morphology since there is no similar species in the Hungarian chrysomelid fauna.

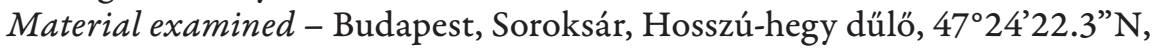
$19^{\circ} 09^{\prime} 54.7$ 'E, hand-collected from Ambrosia artemisiifolia, 6.IX.2020, leg. D. Horváth \& M. Lukátsi (1 male, 1 female, CLM; 1 male, 1 female, CDH); Budapest, Soroksár, Sós-mocsár, 47²4’36.4”N, 1909’23.1”E, swept, 6.IX.2020, leg. D. Horváth \& M. Lukátsi (1 female, CLM); Budapest, Soroksár, Sós-mocsár (Szentlörinciút), $47^{\circ} 25^{\prime} 01.0^{\prime \prime} \mathrm{N}, 1^{\circ} 08^{\prime} 42.5^{\prime \prime} \mathrm{E}$, swept, 6.IX.2020, leg. D. Horváth \& M. Lukátsi (1 male, 1 female, CLM; 2 males, 2 females, HNHM).

\section{DISCUSSION}

Occurrence of $O$. communa in Hungary is not a surprise, its continuous European spreading predicted that it would arrive in Hungary. Since the first data of the species is from Budapest, the capital, industrial and logistic centre of Hungary, it might suggest that it arrived with the international transportation, not by natural extension. The meadows where $O$. communa was found are situated 
next to the M5 motor road, various cargo centres and a wholesale market of fruits and vegetables. Presumably the species has reached the country quite recently, since despite the high abundance of the hostplant, the incidence of $O$. communa was low, while in the Western-European areas where the species settled down earlier there are huge amounts of beetles where the circumstances are right. After our first finding, we visited other suitable areas in Budapest (degraded meadows in Csepel and Budatétény), where ragweed was abundant, but without success. This, and the fact that we carried out specific search for the species in the previous years without any results also suggests its recent arrival.

AUgustinus et al. (2019) predicted the spread of $O$. communa by modelling. They found that most of Hungary is out of the potential distribution area of $O$. communa, so the overwintering and the long-term survival is questionable and require continuous monitoring.

The Hungarian occurrence is remarkable but not only from entomological aspects. Since common ragweed, the main host plant of $O$. communa, is one of the most important weed species in Hungary, the occurrence and possible gradation of $O$. communa could result in the suppression of ragweed and the problems caused by it (SCHAFFNER et al. 2020). However, O. communa is able to feed on sunflower (Helianthus annuus), an important cultivated plant, and this raises concerns for plant protection. O. communa was indeed shown to complete its whole life cycle on sunflower in no-choice laboratory feeding tests (CHEN et al. 2020), but field studies concluded that it prefers ragweed for egg laying and can be found only occasionally on sunflower (ZHOU et al. 2011). According to Swiss and Italian surveys, $O$. communa does not threat any member of the natural vegetation (AUgustinus et al. 2020).

The proposed Hungarian name of $O$. communa: parlagfü-olajosbogár.

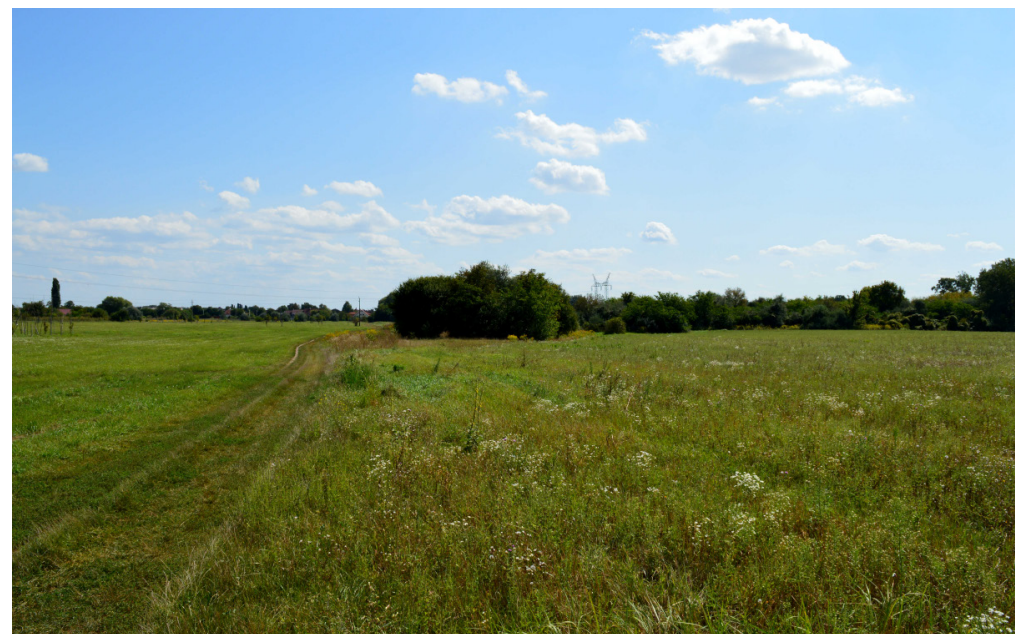

Fig. 1. Habitat of Ophraella communa LeSage, 1986 at Hosszú-hegy dűlő, Soroksár, Budapest (photo by Márk Lukátsi) 


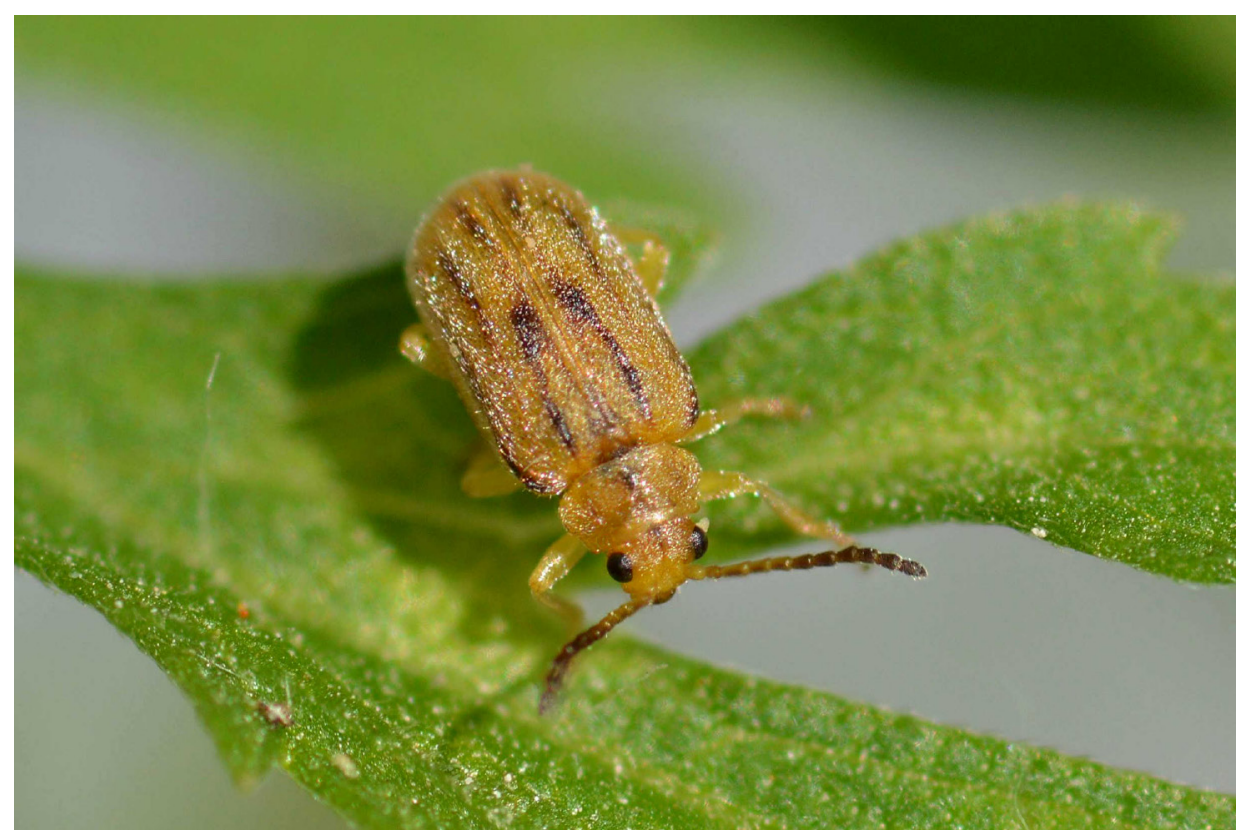

Fig. 2. Ophraella communa on ragweed (photo by Márk Lukátsi)

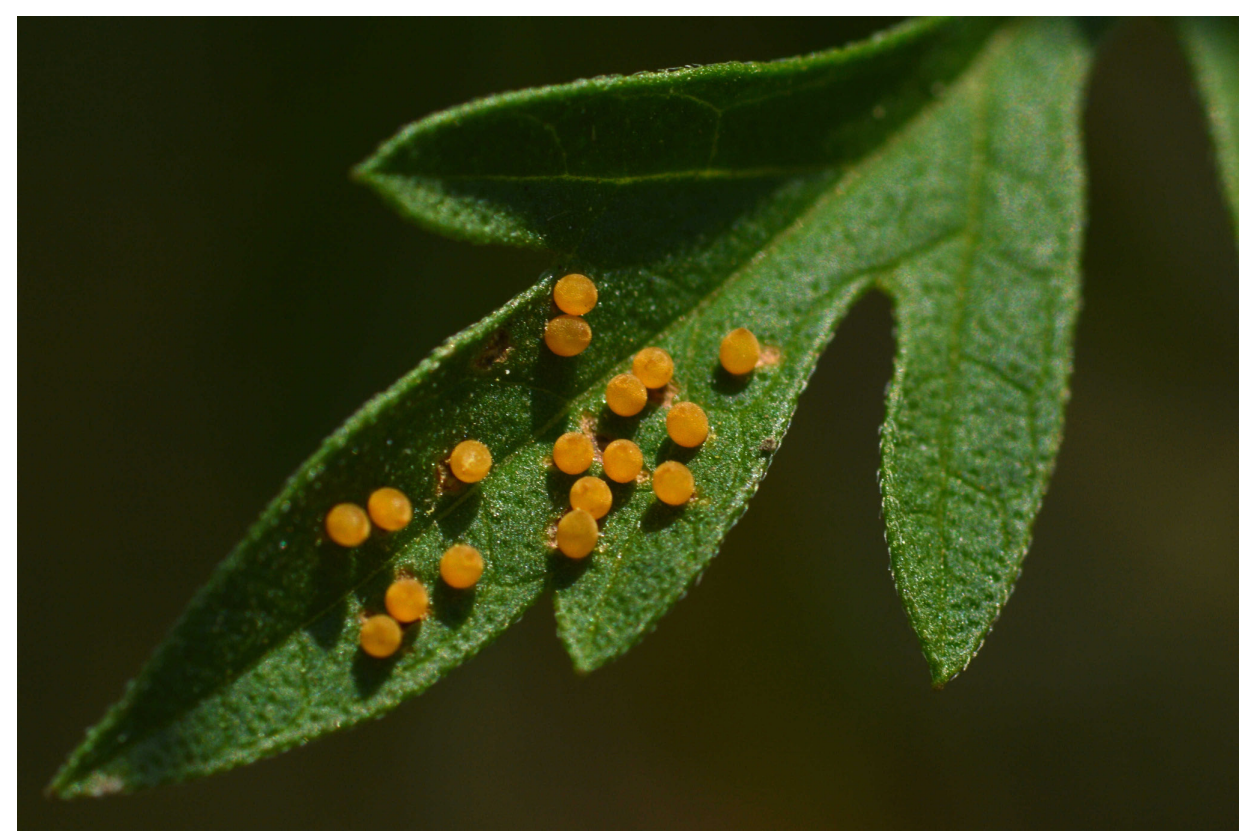

Fig. 3. Egg batch of Ophraella communa on ragweed (photo by Márk Lukátsi) 


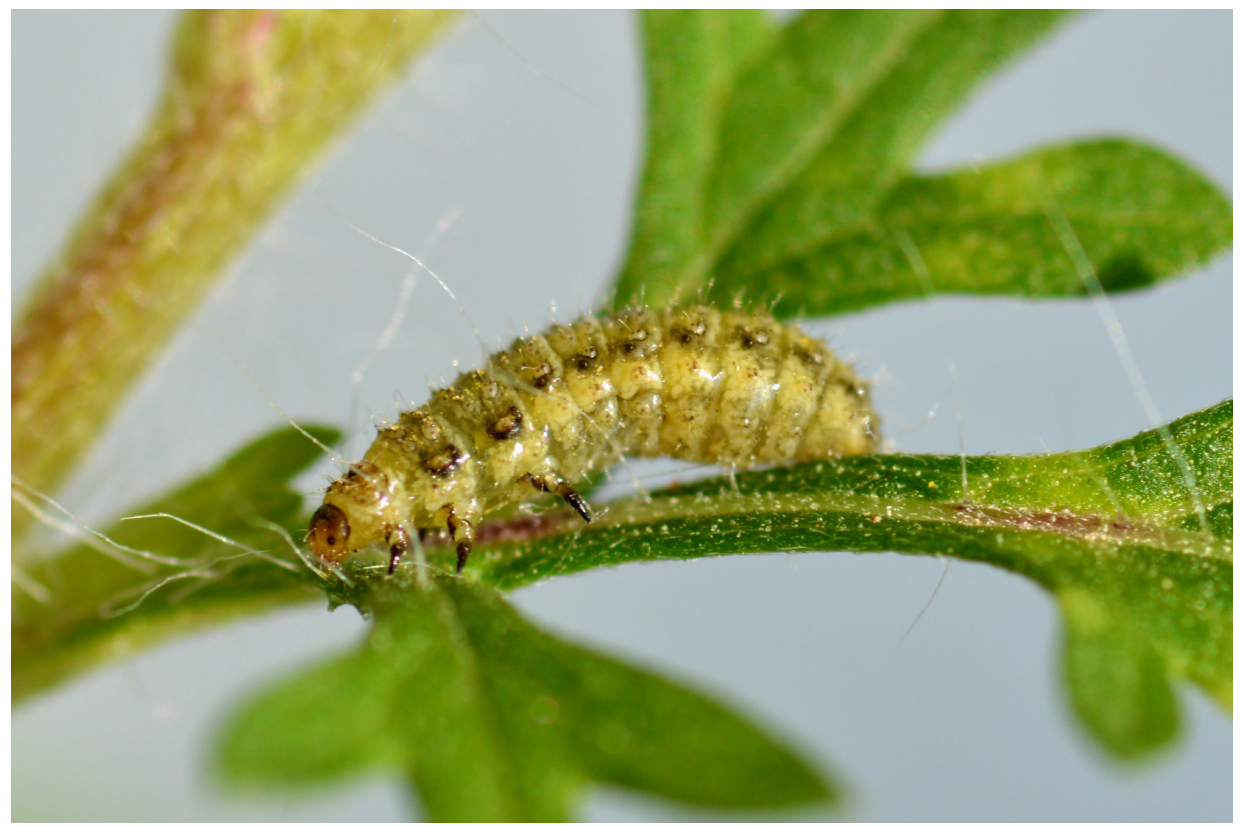

Fig. 4. Last instar larva of Ophraella communa (photo by Márk Lukátsi)

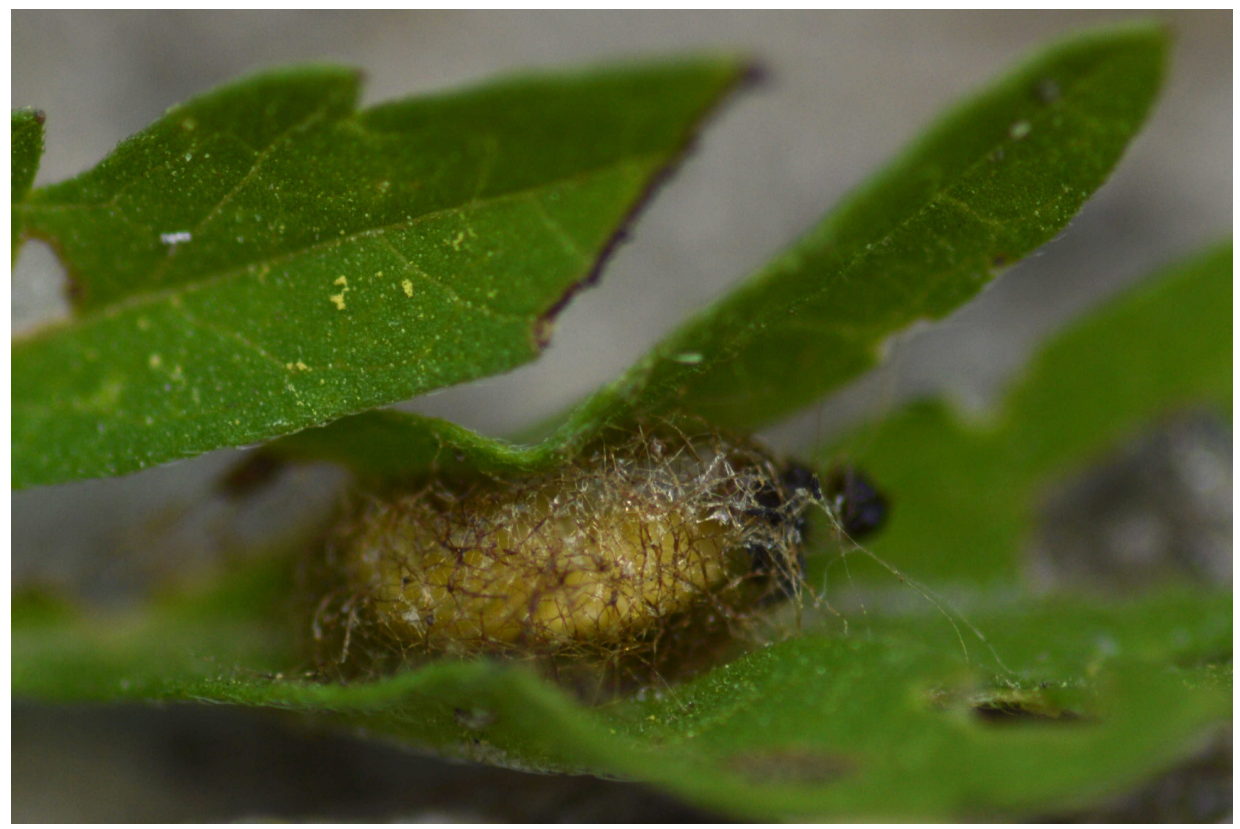

Fig. 5. Pupa of Ophraella communa in its loosely woven cocoon (photo by Márk Lukátsi) 
Acknowledgments - We would like to thank Dénes Tomaschek (Budapest) who uploaded the pictures and the data that we used to find the Ophraella communa population, and Balázs Károlyi (Budapest) for helping the contact and for creating the online platform (https://www.izeltlabuak.hu/) that made this finding possible.

\section{REFERENCES}

Augustinus B. A., Gentili R., Horváth D., Naderi R., Sun Y., Tournet A. T. E., SCHAFFNER U. \& MÜLLER-SCH ÄRER H. 2020: Assessing the risks of non-target feeding by the accidentally introduced ragweed leaf beetle, Ophraella communa, to native European plant species. - Biological Control 150: 104356.

https://doi.org/10.1016/j.biocontrol.2020.104356

Augustinus B., Sun Y., Beuchat C., Schaffner U. \& Müller-Schärer H. 2019: Predicting impact of a biocontrol agent: integrating distribution modeling with climate-dependent vital rates. - Ecological Applications 30(1): e02003. https://doi.org/10.1002/EAP.2003

Chen W.-H., Naoaitoro V., Kafle L., Tseng M.-N. \& Chang T.-Y. 2020: Life History Traits of Ophraella communa (Coleoptera: Chrysomelidae) on Helianthus annuus (Asteraceae). Formosan Entomologist 39: 96-104. https://doi.org/10.6662/TESFE.201908_39(3).002

Gerber E., Schaffner U., Gassmann A., Hinz H. L., Seirer M. \& Müller-Schärer H. 2011: Prospects for biological control of Ambrosia artemisiifolia in Europe: learning from the past. - Weed Research 51: 559-573. . https://doi.org/10.1111/j.1365-3180.2011.00879.x

Goeden R. D. \& Ricker D. W. 1985: The Life History of Ophraella notulata (F.) on Western California (Coleoptera: Chrysomelidae). - Pan-Pacific Entomologist 61: 32-37.

Kazinczi G., Béres I., Novák R., Bíró K. \& Pathy Zs. 2008: Common ragweed (Ambrosia artemisiifolia): a review with special regards to the results in Hungary. I. Taxonomy, origin and distribution, morphology, life cycle and reproduction strategy. - Herbologia 9(1): 55-91.

LeSAge L. 1986: A Taxonomic Monograph of the Nearctic Galerucine Genus Ophraella Wilcox (Coleoptera: Chrysomelidae). - Memoirs of the Entomological Society of Canada 133: 1-75. https://doi.org/10.4039/entm118133fv

Müller-Schärer H., Lommen S. T. E., Rossinelli M., Bonini M., Boriani M., Bosio G. \& SCHAFFNER U. 2014: Ophraella communa, the ragweed leaf beetle, has successfully landed in Europe: fortunate coincidence or threat? - Weed Research 54: 109-119. https://doi.org/10.1111/wre.12072

Schaffner U., Steinbach S., Sun Y., Skjøth C. A., de Weger L. A., Lommen S. T., Augustinus B. A., Bonini M., Karrer G., Šikoparija B., Thibaudon M. \& MüllerSCH ÄRER H. 2020: Biological weed control to relieve millions from Ambrosia allergies in Europe. - Nature Communications 11: 1745. https://doi.org/10.1038/s41467-020-15586-1

Zadravec M., Horvatić B. \& PrPić P. 2019: The Balkans invaded - first record of Ophraella communa LeSage, 1986 (Coleoptera: Chrysomelidae) in Croatia. - BioInvasions Records 8(3): 521-529. https://doi.org/10.3391/bir.2019.8.3.07 
Zandigiacomo P., Boscutti F., Buian F. M., Villani A., Wiedemeier P. \& Cargnus E. 2020: Occurrence of the non-native species Ophraella communa on Ambrosia artemisiifolia in north-eastern Italy, with records from Slovenia and Croatia. - Bulletin of Insectology 73(1): 87-94.

Zhou Z.-S., Guo J.-Y., Zheng X.-W., Luo M., Chen H.-S. \& WAN F.-H. 2011: Reevaluation of biosecurity of Ophraella communa against sunflower (Helianthus annuus). - Biocontrol Science and Technology 21(10): 1147-1160.

http://dx.doi.org/10.1080/09583157.2011.606559 